\title{
Penyusunan Standard Operating Procedures (SOP) Pada Dinas Pendidikan Kabupaten Bengkayang Dalam Rangka Peningkatan Mutu Manajemen Organisasi
}

\author{
Herry Sanoto \\ herry.sanoto@uksw.edu \\ Fakultas Keguruan dan Ilmu Pendidikan, Universitas Kristen Satya Wacana, Salatiga \\ Development Of Standard Operating Procedures (SOP) In Bengkayang District \\ Education Department In Improving Organizational Quality Management
}

\begin{abstract}
This study aims to prepare SOP for organizational management at the Bengkayang Regency Education Office. This research is a qualitative descriptive study with the following steps: (1) preliminary study, (2) planning, and (3) implementation. The subject of this research is the Bengkayang Regency Education Office. The data collection techniques used were interviews and observation. The results of interviews and observations were analyzed by reducing data, presenting data, and drawing conclusions. The results of the preliminary study show that the Bengkayang Regency Education Office does not yet have a Standard Operating Procedure (SOP) for organizational management. SOP preparation is carried out by making field notes on mentoring activities and compiling SOP formats. Meanwhile, the implementation of SOP preparation assistance is carried out in six stages, namely the preparation stage, the formation of an implementation team, planning, drafting, testing SOP drafts, and implementing SOPs. SOPs needed to regulate quality assurance of organizational management.
\end{abstract}

Keywords: Standard Operating Procedures, Educational Department, Quality Assurance, Organizational Management, Qualitative Descriptive

Received date: 25 Agustus $2020 \quad \begin{gathered}\text { Article Info } \\ \text { Revised date: } 4 \text { September } 2020 \quad \text { Accepted date: } 24 \text { September } 2020\end{gathered}$

\section{PENDAHULUAN}

Dalam suatu organisasi, baik swasta atau pemerintah, perlu dibentuk suatu komitmen bersama agar organisasi tersebut menjadi maju dan berkembang. Satu hal yang sangat penting dalam organisasi adalah adanya pedoman dan petunjuk yang terstruktur dalam menjalankan tugas pokok dan fungsinya masing-masing. Tidak terkecuali dalam lingkungan pemerintah, pedoman dan petunjuk terstruktur merupakan aspek penting dalam rangka mewujudkan birokrasi yang memiliki kriteria efektif, efisien dan ekonomis. Kebijakan Reformasi Birokrasi yang ada di Indonesia bertujuan untuk dapat membangun profil pegawai dan perilaku pegawai negara yang memiliki produktivitas, integritas, dan bertanggungjawab serta kemampuan dalam memberikan pelayanan prima melalui perubahan pola pikir serta budaya kerja yang ada dalam sistem manajemen pemerintahan. Pada instansi pemerintah, baik di pusat maupun daerah, Reformasi Birokrasi mencakup 8 (delapan) area perubahan utama, yang meliputi: (a). organisasi, (b). tata laksana, (c). peraturan perundang-undangan, (d). sumber daya manusia pegawai, (e). pengawasan, (f). akuntabilitas, (g). pelayanan publik, dan (h). pola pikir dan budaya kerja pegawai. Salah satu perubahan utama dalam Reformasi Birokrasi adalah tata laksana, dimana perubahan ketatalaksanaan pada hakekatnya diarahkan untuk melakukan penataan tata laksana instansi pemerintah yang efektif dan efisien. Upaya penataan tata laksana antara lain diwujudkan dalam bentuk penyusunan dan implementasi Standard Operating Procedures (SOP) atau Prosedur Operasional Standar (POS) Administrasi Pemerintahan dalam pelaksanaan tugas serta fungsi sebagai pegawai pemerintah. Penyusunan dan implementasi SOP merupakan kegiatan yang memerlukan partisipasi secara penuh dari semua unsur pegawai yang ada di dalam institusi pemerintah. Tuntutan partisipasi penuh dari semua unsur institusi ini dilandasi alasan bahwa hanya pegawai yang paling tahu kondisi yang ada di tempat kerja mereka dan yang terkena dampak secara langsung dari perubahan tersebut. 
Penyusunan Standard Operating Procedures (SOP) Pada Dinas Pendidikan Kabupaten Bengkayang

Dalam Rangka Peningkatan Mutu Manajemen Organisasi (Herry Sanoto)

Pada prakteknya, penyusunan SOP yang dilakukan oleh beberapa Kementerian/Lembaga dan Pemerintah Daerah sering ditemukan perbedaan antara pemahaman SOP maupun variasi format dokumen dari SOP yang dihasilkan. Oleh karena itu, maka diperlukan penyempurnaan pedoman SOP untuk dijadikan acuan bagi instansi pemerintah pusat dan pemerintah daerah dalam menyusun SOP. Penyempurnaan pedoman SOP ada didalam PermenPAN Nomor PER/35/M.PAN/06/2012 sebagai pengganti PermenPAN Nomor PER/21/M.PAN/11/2008. Tujuan dari kegiatan Penyusunan Standard Operating Procedure Berbasis Teknologi Informasi di Dinas Pendidikan Kabupaten Bengkayang ini adalah untuk memberikan panduan dalam menjalankan tupoksi bagi aparat pegawai negeri sipil di lingkungan Dinas Pendidikan Kabupaten Bengkayang, dimana di dalam proses kegiatan ini dilakukan dengan cara mengidentifikasi SOP, menyusun SOP, mendokumentasikan SOP, mengembangkan SOP, memonitor SOP serta mengevaluasi SOP sesuai pada PermenPAN Nomor PER/35/M.PAN/06/2012. Diharapkan, dengan tersusun dan dipergunakannya dokumen SOP ini dengan semestinya, akan menghasilkan hal-hal sebagai berikut: (a). Setiap instansi pemerintah sampai dengan unit yang terkecil memiliki SOP masing-masing; (b). Penyempurnaan proses penyelenggaraan pemerintahan; (c). Ketertiban dalam penyelenggaraan pemerintahan; dan (d). Peningkatan kualitas atau mutu pelayanan kepada masyarakat.

\section{KAJIAN PUSTAKA}

Penelitian mengenai penyusunan Standar Operasional Prosedur (SOP) pernah dilakukan oleh Asih, dkk. (2018), dengan judul: "Penyusunan Standard Operating Procedure (SOP) Produksi Produk Inovasi Ecobrick". Penelitian ini membahas tentang semakin meningkatnya sampah plastik yang ada di Indonesia, membuat para warga sekitar Bank Sampah Brontokusuman RW 20-22 Yogyakarta memproduksi ecobrick. Ecobrick merupakan salah satu cara yang digunakan untuk penanganan limbah plastik dengan mengemas plastik yang sudah bersih dan kering ke dalam botol plastik hingga kerapatan yang ditentukan. Saat ini permasalahan yang ditemukan belum adanya standard operating procedure (SOP) untuk produksi ecobrick. Hal ini menjadi latar belakang peneliti dalam melakukan penelitian ini. Tujuan penelitian ini untuk menyusun produksi SOP ecobrick yang terstruktur dan sistematis sehingga mampu terjaga kualitas dan konsistensi produk yang dihasilkan baik dari segi berat produk maupun estetika. Penelitian ini merupakan penelitian kualitatif. Teknik pengumpulan data yang digunakan dalam penelitian ini adalah observasi, wawancara, dan doukumentasi. Wawancara dilakukan pada pelaku dan pakar (SOP) Produksi Produk Inovasi Ecobrick. Teknik analisis data yang digunakan dalam penelitian ini adalah reduksi, evaluasi dan penarikan kesimpulan. Penelitian ini diharapkan dapat menyajikan pembuatan rancangan SOP awal, rancangan simulasi SOP produksi awal dan identifikasi permasalahan, serta merancang perbaikan maupun pembuatan rancangan dan simulasi akhir. Penelitian ini diharapkan mampu menghasilkan SOP produksi ecobrick yang memiliki nilai estetika serta berat yang terstandar. A aplikasi E-Performance merupakan aplikasi.

Penelitian ini relevan dengan penelitian yang dilakukan Wicaksana, dkk. (2016) menyebutkan bahwa salah satu aplikasi yang dikembangkan oleh Bina Program Pemerintah khususnya kota Surabaya yaitu aplikasi E-Performance. Aplikasi E-Performance merupakan aplikasi yang mampu mengontrol kinerja individu pada masing-masing Satuan kerja Perangkat daerah (SKPD). Aplikasi E-Performance yang dikembangkan belum dilengkapi dengan standar penyelenggaraan proses dalam mengelola level hak akses, terlepas dari kompeksitas aplikasi karena melibatkan berbagai level pengguna aplikasi yang berbeda. Permasalahan yang timbul pada penelitian ini adalah terjadinya redudansi peran (roles) yang dapat berpotensi pada penyalahgunaan wewenang. Prosedur operasional standar (SOP) yang ada memastikan para perilaku pengguna sistem sesuai dengan standar yang diacu. Fokus penelitian ini adalah mengembangkan dan menyusun SOP melalui analisis kesenjangan kondisi kekinian dengan kondisi ekspektasi (ideal) untuk membangun manajemen akses. Hasil penelitian ini diharapkan mampu menghasilkan 6 prosedur dan 12 formulir. Langkah-langkah pengelolaan akses dideskripsikan dalam dokumen prosedur dan formulir. Adanya dokumen SOP diharapkan mampu mengontrol penggunaan aplikasi yang ada berdasarkan level hak akses yang dimiliki oleh masing-masing pengguna sekaligus melindungi aset informasi yang bersifat rahasia.

Tjipto (2010) menjelaskan bahwa Standar Operasional Prosedur (SOP) merupakan acuan atau pedoman yang digunakan untuk menilai pelaksanaan kinerja suatu instansi berdasarkan pada indikator - indikator administratif, indikator-indikator teknis dan prosedural sesuai dengan tata hubungan kerja 
dalam organisasi yang bersangkutan. SOP bertujuan untuk menciptakan komitmen yang dikerjakan oleh setiap unit kerja. SOP dapat digunakan pada semua unit kerja, baik unit kerja pemerintahan maupun unit kerja yang berupa lembaga pendidikan. Selain itu SOP juga dapat digunakan untuk menilai mutu kinerja suatu organisasi tertentu. Standard Operating Procedures (SOP) merupakan serangkaian instruksi tertulis yang telah dibakukan terkait dengan bagaimana dan kapan harus dilakukan, dimana dan oleh siapa SOP dilakukan serta proses penyelenggaraan aktivitas organisasi tersebut. SOP teknis adalah prosedur standar yang sangat terinci dari kegiatan yang dilakukan oleh satu orang pelaksana/pegawai dengan satu peran atau jabatan. Sedangkan SOP administratif merupakan prosedur standar yang bersifat umum dan tidak rinci dari kegiatan yang dilakukan oleh lebih dari satu orang pegawai atau pelaksana dengan lebih dari satu jabatan atau peran. Pihak pelaksana Pelaksana standar Operasional Prosedur (SOP) adalah semua orang yang berada pada organisasi yang menerapkan SOP. Mulai dari pejabat tinggi hingga pegawai terendah yang merupakan pihak pelaksana SOP. Oleh karena itu semua orang yang menjadi bagian dari pelaksana organisasi merupakan pihak pelaksana SOP.

Manfaat Operasional Prosedur (SOP) yaitu: (a). Sebagai standarisasi cara yang dilakukan pegawai dalam menyelesaikan pekerjaan yang menjadi tugasnya; (b). Meningkatkan efisiensi dan efektivitas pelaksanaan tugas dan tanggung jawab individual pegawai dan organisasi secara keseluruhan; (c). Mengurangi tingkat kesalahan dan kelalaian yang mungkin dilakukan oleh seorang pegawai atau pelaksana dalam melaksanakan tugas; (d). Membantu pegawai menjadi lebih mandiri dan tidak tergantung pada intervensi manajemen, sehingga akan mengurangi keterlibatan pimpinan dalam pelaksanaan proses sehari-hari; (e). Menciptakan ukuran standar kinerja yang akan memberikan pegawai cara konkrit untuk memperbaiki kinerja serta membantu mengevaluasi usaha yang telah dilakukan; (f). Meningkatkan akuntabilitas pelaksanaan tugas; (g). Memastikan pelaksanaan tugas penyelenggaraan pemerintahan dapat berlangsung dalam berbagai situasi; (h). Memberikan informasi mengenai kualifikasi kompetensi yang harus dikuasai oleh pegawai dalam melaksanakan tugasnya; (i). Menjamin konsistensi pelayanan kepada masyarakat, baik dari sisi mutu, waktu, dan prosedur; (j). Memberikan informasi bagi upaya peningkatan kompetensi pegawai; $(\mathrm{k})$. Memberikan informasi mengenai beban tugas yang dipikul oleh seorang pegawai dalam melaksanakan tugasnya; (l). Sebagai instrumen yang dapat melindungi pegawai dari kemungkinan tuntutan hukum karena tuduhan melakukan penyimpangan; (m). Membantu penelusuran terhadap kesalahan-kesalahan prosedural dalam memberikan pelayanan; (n). Menghindari tumpang tindih pelaksanaan tugas; dan (o). Membantu memberikan informasi yang diperlukan dalam penyusunan standar pelayanan, sehingga sekaligus dapat memberikan informasi bagi kinerja pelayanan.

Suatu SOP yang tersusun harus memenuhi prinsip-prinsip di bawah : (a). Mudah dipahami dan Jelas, artinya prosedur-prosedur SOP yang distandarkan harus dapat dengan mudah dimengerti dan diterapkan oleh semua pegawai, bahkan bisa dipahami dan mudah dimengerti oleh seseorang yang sama sekali baru dalam pelaksanaan tugasnya; (b). Selaras, artinya prosedur-prosedur yang distandarkan harus selaras dengan prosedur-prosedur standar lain yang terkait; (c). Efisien dan efektif, artinya prosedur-prosedur yang distandarkan harus merupakan prosedur yang paling efisien dan efektif dalam proses pelaksanaan tugas; (d). Terukur, artinya output yang dihasilkan dari prosedur-prosedur yang distandarkan memuat standar mutu/kualitas baku tertentu yang diukur melalui pencapaian keberhasilannya; (e). Dinamis, maksudnya prosedur-prosedur SOP yang distandarkan harus dengan cepat dapat disesuaikan dengan kebutuhan peningkatan kualitas pelayanan yang berkembang dalam penyelenggaraan administrasi pemerintahan; (f). Patuh hukum, artinya prosedur-prosedur yang distandarkan harus memenuhi ketentuan dan peraturan-peraturan pemerintah yang berlaku; (g). Berorientasi pada pengguna (pihak yang dilayani), artinya prosedur- prosedur yang distandarkan harus mempertimbangkan kebutuhan pengguna, sehingga dapat memberikan kepuasan kepada pengguna;dan (h). Kepastian hukum, artinya prosedur-prosedur SOP yang distandarkan harus ditetapkan oleh pimpinan sebagai sebuah produk hukum yang ditaati, dilaksanakan dan menjadi instrumen untuk melindungi pegawai atau pelaksana dari kemungkinan tuntutan hukum. Pada dasarnya pihak penyusun SOP adalah pimpinan atau atasan dari suatu organisasi pemerintah. Tetapi pada pelaksanaannya pimpinan/atasan organisasi memberikan tugas kepada tim yang ditetapkan dan ditunjuk berdasarkan surat keputusan. Tim penyusunan SOP yang ditunjuk merupakan perwakilan dari setiap unit/sistem yang berada dalam organisasi tersebut. Kriteria tim yang ditunjuk dalam penyusunan SOP memiliki kemampuan/kompetensi sesuai dengan bidang organisasi tersebut. Tim penyususn SOP didampingi 
Penyusunan Standard Operating Procedures (SOP) Pada Dinas Pendidikan Kabupaten Bengkayang

Dalam Rangka Peningkatan Mutu Manajemen Organisasi (Herry Sanoto)

atasan/pimpinan tetap memperhatikan prosedur-prosedur serta tahapan-tahapan dalam penyusunan SOP sampai dihasilkan SOP yang disepakati.

Setelah tersusun, maka harus dipatuhi beberapa prinsip dalam melaksanakan SOP, yaitu: (a). Komitmen, artinya SOP yang dikembangkan harus dilaksanakan dengan komitmen yang penuh dari seluruh jajaran organisasi, dari tingkatan yang paling rendah dan tertinggi; (b). Konsisten, artinya SOP harus dilaksanakan secara konsisten dari waktu ke waktu, oleh siapa pun, dan dalam kondisi apapun oleh seluruh jajaran organisasi pemerintahan; (c). Mengikat, artinya SOP harus mengikat pelaksana dalam melaksanakan tugasnya sesuai dengan prosedur standar yang telah ditetapkan; (d). Perbaikan berkelanjutan, artinya pelaksanaan SOP harus terbuka terhada $\mathrm{p}$ penyempurnaan-penyempurnaan untuk memperoleh prosedur yang benar-benar efisien dan efektif; (e). Seluruh unsur memiliki peran penting, artinya seluruh pegawai melaksanakan peran-peran tertentu dalam setiap prosedur yang distandarkan. Jika pegawai tertentu tidak melaksanakan perannya dengan baik, maka akan mengganggu keseluruhan proses, yang akhirnya juga berdampak pada terganggunya proses penyelenggaraan pemerintahan; dan (f). Terdokumentasi dengan baik, artinya semua prosedur yang telah distandarkan harus didokumentasikan, sehingga dapat dijadikan acuan atau referensi bagi pihak-pihak yang memerlukan.

\section{METODE PENELITIAN}

Jenis penelitian ini adalah deskriptif dengan pendekatan kualitatif. Langkah-langkah penelitian ini meliputi: (1) studi pendahuluan, (2) perencanaan penelitian, dan (3) pelaksanaan penelitian. Subjek dalam penelitian ini adalah pimpinan dan pegawai di Dinas Pendidikan Kabupaten Bengkayang. Teknik pengumpulan data yang digunakan dalam penelitian ini adalah wawancara dan observasi. Instrumen yang digunakan dalam penelitian ini adalah lembar observasi yang berupa catatan lapangan. Data hasil penelitian yang berupa hasil wawancara dan hasil observasi yang dituliskan pada catatan lapangan berupa deskripsi pelaksanaan pendampingan penyusunan SOP manajemen organisasi di Dinas Pendidikan Kabupaten Bengkayang. Hasil observasi ini dianalisis dengan cara mereduksi data SOP, kemudian menyajikan data SOP, dan menarik kesimpulan dari penelitian. Hasil data pelaksanaan pendampingan penyusunan SOP diseleksi sesuai dengan kebutuhan penelitian, kemudian data tersebut dideskripsikan serta disimpulkan sehingga menghasilkan kesimpulan penelitian.

\section{HASIL PENELITIAN DAN PEMBAHASAN}

Penyusunan SOP dimulai dengan perencanaan yang dilaksanakan dengan membentuk tim yang secara khusus menangani penyusunan dokumen SOP Dinas Pendidikan Kabupaten Bengkayang. Tim Penyusunan SOP dibentuk dengan anggota dari Unit Kerja yang secara fungsional menangani ketatalaksanaan internal Unit Kerja. Unit kerja dapat melibatkan tenaga yang kompeten sehingga bisa menghasilkan SOP yang optimal. Tahap Perencanaan ini menghasilkan : (1). Daftar Kebutuhan Tenaga Ahli dan Tenaga Pelaksana, (2). Jadwal Kerja Tim, (3). Daftar Materi Pendukung dan Materi Utama Penyusunan dokumen SOP berbasis Teknologi Informasi, dan (4). Rencana Kerja Penyusunan Dokumen SOP Berbasis Teknologi Informasi Dinas Pendidikan Kabupaten Bengkayang. Setelah melaksanakan tahap perencanaan maka tim penyusunan SOP mulai melakukan tahap persiapan penyusunan SOP. Tahap perencanaan perlu dikonsultasikan dengan pihak Dinas Pendidikan Kabupaten Bengkayang.

Pada tahap persiapan ini tim yang terbentuk wajib mempelajari dan meneliti berbagai referensi yang ada termasuk didalamnya adalah produk perundangan yang terkait langsung maupun tidak langsung dengan kegiatan penyusunan dokumen SOP di pemerintahan daerah. Tim juga melakukan diskusi terfokus dengan tim dari Dinas Pendidikan Kabupaten Bengkayang untuk menghasilkan kesepahaman dan kesepakatan-kesepakatan dalam penyusunan dokumen SOP ini. Tim mengidentifikasi informasi dengan cara memisahkan mana informasi yang dibutuhkan dari sumber primer dan mana yang dibutuhkan dari sumber sekunder. Hasil identifikasi berbagai informasi yang dikumpulkan selanjutnya tim menentukan teknik informasi yang sesuai. Ada berbagai kemungkinan teknik pengumpulan informasi yang dapat digunakan untuk mengembangkan SOP, seperti melalui brainstorming, interview, survey, benchmarking, focus group discussion, telaahan dokumen dan lainnya. Teknik mana yang akan digunakan, sangat terkait erat dengan instrumen pengumpul informasinya. Tahap persiapan penyusunan ini menghasilkan : (1). Standar Penyusunan SOP berbasis Teknologi Informasi Dinas Pendidikan Kabupaten Bengkayang, (2). Metodologi Penyusunan SOP 
berbasis Teknologi Informasi Dinas Pendidikan Kabupaten Bengkayang, (3). Standar dan aturan dokumen SOP, dan (4). Batasan Teknologi Informasi yang akan dibangun.

Tahap berikutnya adalah verifikasi dengan melakukan pengamatan langsung di lapangan pada saat operasional kerja pegawai Dinas Pendidikan Kabupaten Bengkayang dilakukan untuk memperoleh fakta lapangan tentang pelaksanaan tupoksi disetiap jabatan. Persamaan dan ketidak sesuaian antara fakta dilapangan dengan draft SOP secara langsung mendapat penjelasan terkait hal ini. Pengamatan secara tidak langsung juga dilakukan dengan cara wawancara dan Focus Group Discussion (FGD) bila tupoksi yang melekat pada jabatan tidak / belum dilakukan dlapangan. FGD dengan melibatkan secara langsung beberapa Bidang yang terkait didalam satu tupoksi sangat membantu menemukan aliran proses kerja. Dalam tahap ini ditemukan juga beberapa tupoksi yang berlaku sama untuk sub-Bidang yang berlainan. Pada langkah ini didapatkan hasil-hasil sebagai berikut: (1). Penjabaran tupoksi setiap jabatan, (2). Draft diagram SOP untuk setiap jabatan, dan (3). Dokumentasi/catatan wawancara dan FGD Verifikasi.

Selanjutnya adalah tahapan perumusan dan analisis. Pada tahap ini, dilakukan perbaikan draft SOP dengan mempertimbangkan hasil pada langkah verifikasi. Analisis seperlunya dilakukan terhadap alternatif-alternatif prosedur yang berhasil diidentifikasi untuk dijadikan materi penyusunan dokumen SOP. Tahapan berikutnya menentukan alternatif mana yang dipilih yang meliputi aspek-aspek efisiensi dan efektivitas, kemudahan dan kejelasan, dinamis, berorientasi pada pihak yang dilayani, keselarasan, keterukuran, kesesuaian dengan peraturan perundang-undangan, dan ketaatan hukum. Peneliti membandingkan berbagai alternatif yang ada melalui keuntungan dan kerugian yang kemungkinan terjadi jika diterapkannya alternatif tersebut, selanjutnya dapat dipilih alternatif yang sesuai dan dapat memenuhi kebutuhan organisasi tersebut. Tahap proses analisis ini akan menghasilkan prosedurprosedur SOP, baik berupa penyempurnaan prosedur-prosedur SOP yang sudah ada, maupun pembuatan prosedur-prosedur SOP yang sudah ada tetapi belum distandarkan, ataupun prosedurprosedur SOP yang belum ada sama sekali. Pada tahap ini hasil yang didapatkan adalah : (1). Draft dokumen SOP untuk setiap jabatan, (2). Draft dokumen SOP baru untuk prosedur yang sudah ada tapi belum distandarkan, (3). Draft dokumen SOP baru untuk prosedur yang belum ada.

Tahap penyusunan SOP selanjutnya adalah konfirmasi, pembahasan, dan revisi. Pada tahap ini dilakukan FGD dengan setiap jabatan dalam SOTK Dinas Pendidikan Kabupaten Bengkayang untuk paparan draft dokumen SOP, konfirmasi draft dokumen SOP, pembahasan draft dokumen SOP dan sekaligus merevisi secara langsung draft dokumen SOP yang telah dibahas. Konfirmasi dan Pembahasan draft dokumen SOP dapat diharapkan dapat dilakukan secara efektif dan efisien karena sudah adanya dokumen SOP yang dijadikan materi FGD. Revisi dapat dilakukan secara langsung karena diharapkan perubahanperubahan yang ada dan ditemukan dalam FGD berupa hal-hal minor. Paparan desain SOP Berbasis Teknologi Informasi (Android) dilakukan juga pada tahap ini. Prototipe Android Package Kit (APK) SOP Dinas Pendidikan Kabupaten Bengkayang akan didemokan untuk kemudian didapatkan saran dan masukan untuk memperbaiki APK ini. Belum adanya pedoman/petunjuk format standar pembuatan SOP berbasis Android membuat desain APK ini mengutamakan aspek kemudahan penggunaan dan kesederhanaan desain dengan maksud APK menjadi user-friendly dan ringan diakses berbagai mesin Android. Diharapkan langkah ini sudah dapat menghasilkan dokumen SOP Dinas Pendidikan Kabupaten Bengkayang.

\section{SIMPULAN DAN SARAN}

Dokumen Standard Operating Procedures (SOP) Berbasis Teknologi Informasi di Dinas Pendidikan Daerah Kabupaten Bengkayang ini disusun berdasar pada kondisi riil di lapangan dengan penambahan-penambahan ataupun pengurangan-pengurangan pada beberapa prosedur yang dikarenakan aspek regulasi dan atau kendala pada kondisi yang tidak dapat dihindari. Penyesuaian beberapa prosedur dilakukan karena kondisi di atas tetap tanpa merubah makna prosedur yang dilakukan. Tersedianya dokumen dalam bentuk digital berbasis Android off-line menjadikan dokumen ini dapat diakses setiap saat dan setiap tempat secara mudah dalam aspek penggunaan dan ketersediaan. Dokumen SOP Berbasis Teknologi Informasi di Dinas Pendidikan Daerah Kabupaten Bengkayang ini diharapkan menjadi acuan dalam melaksanakan tupoksi sehingga operasional kerja menjadi jelas, terarah, efisien, efektif, akuntabel, terukur, konsisten dan aman. 
Penyusunan Standard Operating Procedures (SOP) Pada Dinas Pendidikan Kabupaten Bengkayang

Dalam Rangka Peningkatan Mutu Manajemen Organisasi (Herry Sanoto)

\section{DAFTAR PUSTAKA}

PermenPAN Nomor PER/35/M.PAN/06/2012 tentang Pedoman Penyusunan Standar Operasional Prosedur Administrasi Pemerintahan.

Arenawati, Administrasi Pemerintah Daerah; Sejarah Konsep dan Penatalaksanaan di Indonesia, Graha Ilmu, 2014.

Asih, Hayati Mukti, Syifa Fitriani, 2018, Penyusunan Standard Operating Procedure (SOP) Produksi Produk Inovasi Ecobrick, Surakarta: Jurnal Ilmiah Teknik Industri, UMS.

Dadang Suwanda \& Agus Purwoko, Menyusun Standard Operating Procedures Lembaga Pemerintah, PPM, 2014.

Hanif Nurcholis, Administrasi Pemerintahan Daerah, Universitas Terbuka, 2014.

Kementerian Pendayagunaan Aparatur Negara dan Reformasi Birokrasi, Deputi Bidang Tatalaksana, Pedoman Penyusunan SOP Administrasi Pemerintahan, 2013.

Wicaksana, Radita Wildan, Anisah Herdiyanti, Tony Dwi Susanto, 2016, Pembuatan Standar Operasional Prosedur (SOP) Manajemen Akses Untuk Aplikasi E-Performance Bina Program Kota Surabaya Berdasarkan Kerangka Kerja ITIL V3 Dan ISO 27002, Surabaya: Jurnal SISFO, ITS. 